\title{
維持・運搬
}

坑道維持技術は今後ますます重要となろう。技術の開発と併せて骨格造成に考慮することも肝要である。 運搬技術は自動化の取組み易い技術であり，この普及を推進すべきである。

\section{〔3-1] 概説}

\section{Review on Roadway Maintenance and Transportation}

\section{I. 坑 道 維 持}

\section{1. はじめに}

国内の炭鉱では，年々坑内作業現場が深部化あるいは広域化し ており, 坑道維持が重要な課題となつている。第 1 図は, 国内各 炭鉱における年度末維持坑道長 $1 \mathrm{~m}$ 当りの年間払大盤打工数と平 均稼行深度の関係を表わしたもので, 1977〜'79年の平均值である。 同図では,一般に深部化の進んだ炭鉱ほど坑道維持に多くの工数 を費しているが, 三池・池島・三井砂川では坑道維持状況が他の 炭鉱と比較して良好であり, 逆に, 高島・南大夕張・夕張新炭鉱 では平均稼行深度の割に坑道維持状況は悪い。これらは, 地質状 況，採掘方式等の差異によるものである。

悪化する坑道状況の対応策として, 鋼枠部材の重量化 (一部炭 鉱では S M I 125，34.7 kg/m の部材が主流をなしている ), 枠間

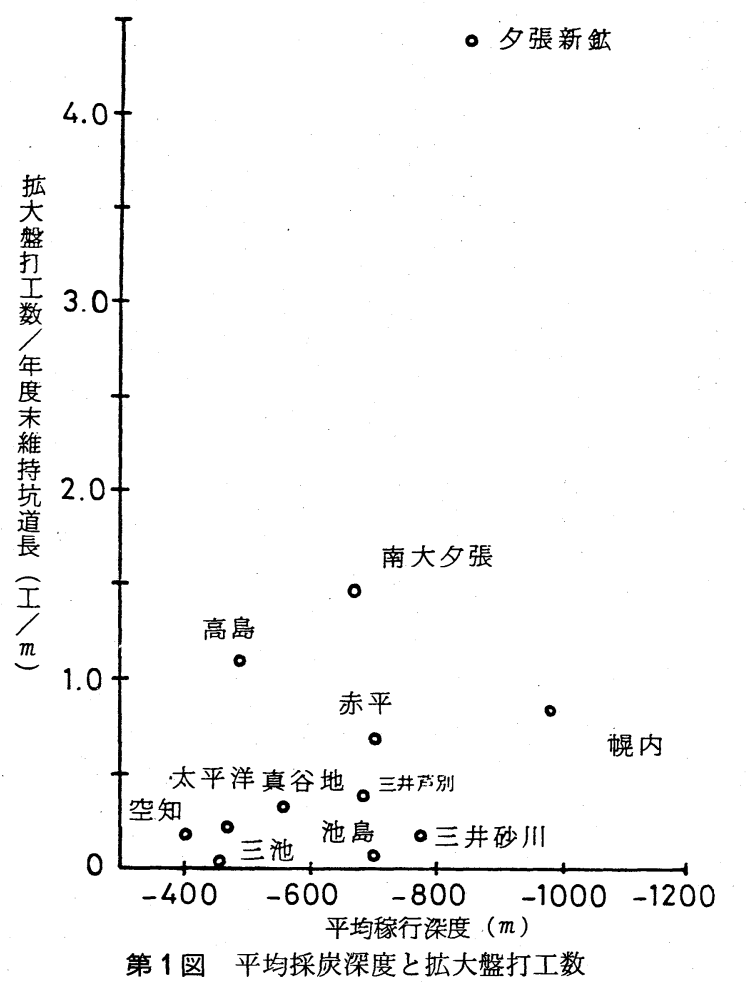

1. (財) 石炭技術研究所第一研究部保安技術第二研究室長

2. (財) 石炭技術研究所第一研究部生産技術第二研究室長

$\begin{array}{lcll}\text { 佐 谷 } & \text { 正 } \text { 幸 }^{1} & \text { 高 } & \text { S } \\ \text { Masayuki SATANII } & & \text { Sakae } & \text { TAKAGI }\end{array}$

を狭くする, 拡大 - 盤打作業の機械化, 袖巻充てんの強化, 坑道 設定箇所の選定等の従来技術の改善に加え，ボルト打設，コンク リート吹付け, 岩盤固結等の現場適用技術の開発も進められた。 さらに, 鉱山用 I 形鋼部材以外の鋼枠部材の検討, 模型を用いて の坑道変形に関する基礎研究も実施されている。

\section{2. 盤打作業の省力化}

盤打作業は最も日常的に行なわれている坑道維持作業であるに もかかわらず，そのほとんどを人力にたよつていた。この作業の 省力化々能率向上を目ざして'79年より石炭技術研究所（石炭技 研 ) が中心となり 4 種類の盤打機の開発を行なつた。これら 4 種 の盤打機の開発の経緯, 仕様, 現場試験結果については本号で紹 介されているが，現場試験段階を終了し，既に実用段階に入つて 来ている。現在これらの艋打機は, 赤平, 三井芦別, 三井砂川, 高島, 池島の各炭鉱で稼動している。

\section{3. ボルト打設}

'73年に坑道支保改善の方法として, 初めて接着支保ボルトが 炭鉱坑内で使用され, その適用性が調査された( 試験現場は高島 炭鉱, 三井砂川炭鉱)。その後, 三池, 三井芦別, 夕張新, 南大 夕張の各炭鉱において各種ボルトを用いた試験が実施された。特 に坑道維持に問題のあつた夕張新炭鉱では, 側壁, 天井部へのボ ルト打設のみならず, 下盤への長尺ボルトやコンクリート吹付け と併用する試験も行なわれた。と同時に, ボルト打設能率および 坑道掘進能率の向上を目的として, ボルトセッタの開発が石炭技 研により行なわれ，現在 3 炭鉱で稼働している。このボルトセッ タの詳細についても本号で紹介されている。

ボルトの打設が坑道維持上効果的であることは現場的に確認さ れているが, 打設効果を定量的に把握し, 地質状況や坑内骨格構 造に見合つた打設規格の確立が今後望まれている。

\section{4. 袖巻充てん強化}

従来緩傾斜および中傾斜層の採炭坑道の維持方法としては, 保 安炭柱を残す方法や, 払跡に崩落したボタを人力で積み上げる手 積充てんが行なわれてきた。しかし， 70 年代に入り, フライア ッシュまたは選炭スラッジを水力で輸送して袖巻充てんを形成す る方法に切り替えられてきた。さらに, 脱水後の天盤と充てんと の空隙を小さくし, 充てん自体に強度をもたせる目的で, フライ アッシュや選炭スラッジの混合液に, セメントを混ぜて充てんす る方法が試みられ成果を上げている。 
また一部急傾斜欠口切羽の肩坑道維持の目的で, 碰充てんに加 え選炭スラッジ，セメント混合液を充てんする方式が採用され効 果を上げている。

\section{5. 坑道設定位置・時期の選定}

深部移行に伴い増大する地圧の作用あるいは採炭切羽の先行圧 の作用を回避する目的で, 採炭により地圧の解放された区域に坑 道を設定する方式が試みられている。例えば，南大夕張炭鉱での 盤下追掛方式, 高島炭鉱における肩坑道追掛方式, 太平洋炭鉱に おける払跡ライナ坑道等がその例であり，いずれも坑道維持上良 い結果を得ている。

\section{6. こ の 他}

上記の外, 石炭技研では地層模型試験装置を赤平研究室に設置し, 坑道の変形,ボルト支保の効果, 袖巻充てんの効果等の基礎的研究を 行なつている。同様の研究は九大, 東大においても実施されている。 さらには, 鉱山用 I 形鋼に代わる $\mathrm{H}$ 形鋼支保の試作や I 形鋼用 の可縮継目板の試作も行なわれているが, いずれも研究段階である。 ウレタンによる岩盤固結は, 最初幌内鉱で試みられ, 石炭技研 により’76 年から, 幌内鉱, 夕張新鉱, 赤平鉱, 釧路鉱, 高島鉱 において基礎研究が行なわれた その後も幌内鉱, 夕張新鉱, 赤 平鉱等においては継続的に実施され, また近年真谷地鉱では止水 をかねた岩盤固結にウレタンが使用されている。

\section{II. 運搬}

\section{1.はじめに}

'60 年代の運搬技術における最大の変革は, 大容量, 長スパン のベルトコンベヤが急速に導入され定着したことである。その後 ’70 年代には, 画期的な運搬技術の発達は見られないが, センサ 一技術, 伝送技術, エレクトロニクス等周辺技術の発達に伴い, 保安と生産の省力面での要請による運搬の集中監視, 自動運転, 遠隔操作が普及した。その他には，'55 年頃使用されその後姿を 消したディーゼルロコが，衣替えをして，炭鉱の深部化，奥部化 に対処するため高速，大容量運搬を目指してバッテリーロコに替 るものとして注目されている。また炭鉱の深部化，奥部化に対応 する運搬の合理化工事が三池, 三井芦別, 太平洋, 池島炭鉱等で 実施された。

\section{2. 集中監視, リモコン化}

\section{$2 \cdot 1$ ベルトコンベヤの集中監視・制御}

' 70 年 8 月営業出炭開始した南大夕張炭鉱は坑内外設備の集中 監視制御，保安計測監視の自動化を目的として中央管制室を導入 し，その中にベルトコンベヤの監視装置も組込まれた。その後各炭 鉱とも逐次中央管制装置を導入し，主要全炭鉱に普及するに至つ た。ベルトコンベヤの集中監視，制御内容は監視，遠隔操作，自 動運転に大別されるが，各鉱とも大同小異であり，一例として三 井芦別鉱深部揚炭ベルトの監視・制御設備は第 1 表の通りであり テレビを含む15項目を監視している。各鉱ともこれによつて事故 の予防, 早期復旧, 省力化等に成果をあげている。更に出炭量の 変化に合わせてコンベヤ運転速度を調整する省動力化の試みもな されている。

\section{$2 \cdot 2$ 斜坑巻の自動化リモコン化}

大型斜坑巻は通常巻線型誘導電動機が使用され, その運転はピ ン切り, ピン差し等の巻立操作が必要なため, 運転手は棹取か らの単打信号を判断して操作している。そのため信号の聞き違い
第 1 表 監視設備一覧表

\begin{tabular}{|c|c|c|c|c|c|}
\hline \multicolumn{2}{|r|}{ 監 視 項 目 } & $\begin{array}{l}\text { 警 報 } \\
\text { ブザー }\end{array}$ & しや断 & $\begin{array}{l}\text { 監視盤 } \\
\text { 表 }\end{array}$ & 備 考 欄 \\
\hline \multirow{4}{*}{ 保 } & ベルト片寄り & 0 & & $\bigcirc$ & 検出器 5 組 \\
\hline & ベルトスリップ & $\bigcirc$ & $\bigcirc$ & 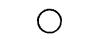 & スリップリレー \\
\hline & ベルト, フィーダ & 0 & 0 & & サーマルリレー \\
\hline & ベルトテークアップ & $\bigcirc$ & $\bigcirc$ & & リミットスイッチ \\
\hline \multirow[t]{2}{*}{ 安 } & シュート詰り & O & 0 & & レベルスイッチ \\
\hline & ベルト縦裂 & $\bigcirc$ & $\bigcirc$ & $\bigcirc$ & 微電流リレー \\
\hline \multirow[t]{2}{*}{ 設 } & メタル加熱 & O & O & & $\begin{array}{l}\text { セソスビーと微 } \\
\text { 雷流リレー }\end{array}$ \\
\hline & 電磁ブレーキ不良 & 0 & O & $\bigcirc$ & リミットスイッチ \\
\hline \multirow[t]{3}{*}{ 備 } & $\begin{array}{c}\text { リアクトル投入 } \\
\text { 不 }\end{array}$ & $\bigcirc$ & $\bigcirc$ & $\bigcirc$ & タイムリレー \\
\hline & 火 & 0 & & D & $\begin{array}{l}\text { 差動式温度感知 } \\
\text { 器 }\end{array}$ \\
\hline & 非 常 停 止 & O & 0 & 0 & 8 個 \\
\hline $\begin{array}{l}\text { 計 } \\
\text { 測 }\end{array}$ & 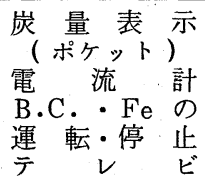 & & & $\begin{array}{c}0 \\
0 \\
\text { モニター }\end{array}$ & $\begin{array}{l}\text { 満・中・空, ポケ } \\
\text { ッ } 3 \text { 箇所 } \\
2 \text { 台 } \\
\text { ランプ表示 } \\
3 \text { セット }\end{array}$ \\
\hline
\end{tabular}

によるトラブルがあり，また脱線直しや函の入替等複雑な操作を 迅速に思い通りにできない不便があつた。これらのトラブル防止 と運搬の省力化のために，石炭技研では，'76 年, ’ 77 年度にわ たり，三井芦別第二坑副卸 $350 \mathrm{~kW}$ 斜坑巻を棹取によるワンマ ンリモコン方式に改造して実操業に供した。

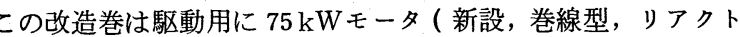
ル制御）と $175 \mathrm{~kW} \times 2$ モータ（既設，巻線型，金属抵抗制御）を 新設のスーパ・インポウズ遊星霜車減速機に接続し，これにリニ ア・モータ制動装置を組合わせて, 安定した低速，中速，高速と スムーズな加減速制御ができるようにしたものである。なお,リ モコン用の制御信号は従来通りの単打信号をそのまま使用し, 本 線部分の自動運転は深度指示計に取り付けたりミットスイッチ, 軌道内のレールスイッチで行なうとともに, スケジュール解除用 フレキシブル型リミットスイッチ ( $50 \mathrm{~m}$ 間隔), 復帰用押ボタン式 スイッチ ( $100 \mathrm{~m}$ 間隔)を取付け運転の安全が図られた。更に’78 年にはスケジュール解除用に超短波誘導無線装置を付加し安全性 が向上した。

その後三井芦別炭鉱は芦別斜坑巻 (新設, 人車・材料巻 ) にこ のリモコン方式を採用し, 釧路炭鉱でも， 79 年 4 月新設運転開 始した中央第 2 斜坑 $700 \mathrm{~kW}$ 巻に自動運転方式を採用した。また 高島炭鉱10卸の新設 $600 \mathrm{~kW}$ 巻 もこの方式で' 83 年 3 月に稼働開 始予定 (仮巻) である。その他, 棹取と巻運転手の間の従来の引 網または押ボタン式信号の無線方式化は南大夕張鉱その他で多く 採用され安全性の向上に寄与している。

\section{$2 \cdot 3$ 立坑巻の自動化}

立坑巻のスキップ巻は早くから自動化され，運転状態は管制室 に表示し, 積込排出状況はテビで監視されているが, 三井砂川炭 鉱のスキップ巻は自動検量を行なつている('65 年頃)。そのほか この方式を採用している炭鉱は多い。

$2 \cdot 4$ エンドレス巻のリモコン化

釧路炭鉱では末端坑道の運搬にはテール巻を用いていたが， '80年に石炭技研の協力を得, これに代りリモコンのエンドレス巻を 採用した。このリモコンはラジオコントロール設備を用い, 送信 器は 3 チャンネルで, 正・逆運転信号はデットマン方式で, 3 段 階の順次スピード切替 $(15 \mathrm{~m} / \mathrm{min}, 30 \mathrm{~m} / \mathrm{min}, 60 \mathrm{~m} / \mathrm{min})$ も可能 である。この方式の採用により, 運搬段数の減少, ワイヤロープ 保護とともに，運転手減による省力化ができた。 
$2 \cdot 5$ バッテリーロコのリモコン化

バッテリーロコ操車のワンマン化による省力化と, 運転手〜棹 取間の信号ミスによる事故の防止を目的に，'74 年石炭技研は芦 別炭鉱との共同によりリモコンバッテリーロコを開発した。本機 は棹取の携行する無線操緃装置 ( F M 変調誘導無線方式) で操作 される。操作機能は, 手動操作と同様に, 前 - 後進切替, ノッチ $1 \cdot 2 \cdot 3$, 強・弱ブレーキ, 砂散きの 8 要素を持つている。更 にフェールセーフ方式によるブレーキの ON・OFF，後押しの場 合のロコと先導車の組合せ等により安全性の向上が図られ，充て ん作業や炭積み作業に定着した。

\section{$2 \cdot 6$ その他}

芦別炭鉱の坑内充てん碰積込みの $\mathrm{G} \cdot \mathrm{M} \cdot \mathrm{C}$ による自動化, 赤平鉱 の油圧式自動チップラー等が挙げられる。

$$
\text { 3. ディーゼルロコ }
$$

ディーゼルロコは’55 年以降片盤運搬等にかなり使用されたが, 排気ガスによる坑気の污染, 保守管理要員不足等の問題から簡便 なバッテリーロコにとつて替られ，国内からは姿を消した。その 後, 防爆エンジンの効率向上, 排ガス処理技術の改善, 駆動方式 のトルクコンバータから油圧方式（オイルポンプとオイルモータ） への転換等各種技術の向上の結果，バッテリーロコに較べて，1) 全効率がよい，2）速度，牽引力を大きくできる，3）燃料の軽 油は大量のバッテリーより安全である等の有利な面が注目されるよ うになり, 従来より改善された形で再登場することとなつた。 諸外国では既に多数使用されているが，釧路炭鉱では，1）現
行水平主要運搬の速度向上と安全性向上 (バッテリーロコの代替), 2) 将来の問題として, 深部化, 奥部化の場合のトロリーロコの 代替と定置式機械のノンヶーブル化の基礎固めの目的で，'82 年 11月に西独製のディーゼルロコを中央西一片材料坑道の人車, 材 料運搬に導入した。導入に際しては, 彼我防爆検定基準のギャッ プを埋める技術的努力が必要であつた。本機の概要は次の通りで ある。

1) メーカ：ルアターラ社，2）重量：10 t，3) 寸法 (mm) : 5,300 長 $\times 930$ 幅 $\times 1,650$ 高, 4) 馬力: $94 \mathrm{H}, 5)$ 速度 $18 \mathrm{~km} / \mathrm{h}$ 。 なお石炭技研では来る 6 月には国産のディーゼルロコを赤平炭鉱 で試験する予定で準備中である。

\section{4. そ の 他}

1) 人員輸送ではロープリフトが’ 72 年頃から各山の昇り人道 に用いられ, 定着し, 三池の宮浦釷 ('74 年 6 月), その他ではマ ンベルトが使用された。また高島炭鉱, 三池の四山鉱( $26 \mathrm{t}$ トロリ 一, $18 \mathrm{~km} / \mathrm{h} \rightarrow 24 \mathrm{~km} / \mathrm{h})$ では水平人車の高速化が行なわれた。 2）局部運搬としては西独製のモノレールが赤平炭鉱の自走枠運 搬 ('77 年頃), 三池三川鉱のクーラー移設 ('77 年 8 月), 南大夕 張炭鉱の $500 \mathrm{~mm}$ 大口径採掘機の本体およびロッド運搬('82年)にそ れぞれ用いられたが，各炭鉱の普及には今一歩の観がある。3) 試 験段階のものとしては, ディーゼルトラック ('77年, 石炭技研, 三池 四山鉱 )，防爆バッテリーワゴン('75年，石炭技研，三池四山鉱）， コンベヤの液圧駆動 ('82年, 石炭技研, 高島炭鉱・砂川炭鉱)等 が挙げられる。

\section{〔3-2〕南大夕張炭鉱における骨格構造の改善}

\section{1. まえがき}

三菱南大夕張炭鉱は, 昭和 41 年 10 月開発工事に着工, 昭和 45 年 8 月営業出炭を開始し，今日まで13年間にわたりほぼ順調に操業 を続けている。現在の生産規模は，年産 100 万 $\mathrm{t}, 4$ 払体制で原料 炭生産を主体としている。

当鉱は地質構造が複雑で, 断層褶曲が多数介在し, 炭盤は脆弱 で, 炭層には多量のメタンガスを包蔵しており，採掘条件はきわ めて厳しいものがある。このような劣悪な自然条件のもとで, 骨 格構造を整備し, 地山ガス拔きを徹底的に実施して後退式採炭切 羽を維持して来た。その間坑道維持を中心に幾多の問題点に遭遇 し, 改善を重ねて来た結果, 採掘区域の深部移行にも拘わらず, 坑道維持状況は逐次好転し, 生産保安の確保に寄与している。

\section{2. 炭 鉱 概 況}

\section{$2 \cdot 1$ 地質状況}

当鉱は石狩炭田の南端に位置し, 鉱区は東西 $6 \mathrm{~km}$, 南北 $9 \mathrm{~km}$ にわたる。

地質は白亜紀層を基盤とし，その上位に累重する古第三紀石狩 層群，および幌内層より構成されている(第 1 図参照)。

地質構造は, 造山作用による東方よりの強大な横圧力により過

1. 三菱石炭鉱業株式会社南大夕張矿業所副所長
照 沼 真 文 $^{1}$

褶曲構造を呈し, 西より遠幌, 南大夕張, 大夕張の 3 大向斜を形 成している (第 2 図参照)。

当鉱の当面の稼行対象区域は, 中央部の南大夕張向斜順層部で 稼行対象炭層は上層, 本層, 下層の 3 層であり, 傾斜は $15 \sim 45^{\circ}$ で褟曲が多く多数の断層が介在している。

\section{$2 \cdot 2$ 坑内構造}

(1) 基幹構造 基幹構造は, 地質, 炭層賦存状況および立地 条件等を考慮し，可能な限り良 質岩盤である幌内層，若鍋層内 に設定する方針のもとに，4 斜 坑， 1 立坑の組み合わせ方式と し, SL- $125 \mathrm{~m}$ に本片坑道およ び本片連坑道を設定し, 斜坑, 立坑相互の連けいを困つた（第 3 図参照 )。

（2）区画構造 本片坑道よ り盤下卸をほぼ $500 \mathrm{~m}$ 間隔に設 定し，片盤盤下坑道を $60 \sim 80 \mathrm{~m}$ の水準間隔で展開, 立入坑道, 盤上坑道, 沿層坑道等により区 画構造を構成している。

当地区の宿命として, 区画構

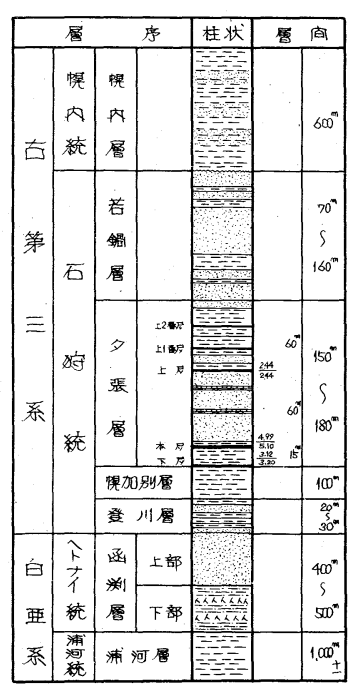

第 1 図 地質柱状図

$682<80>$ 